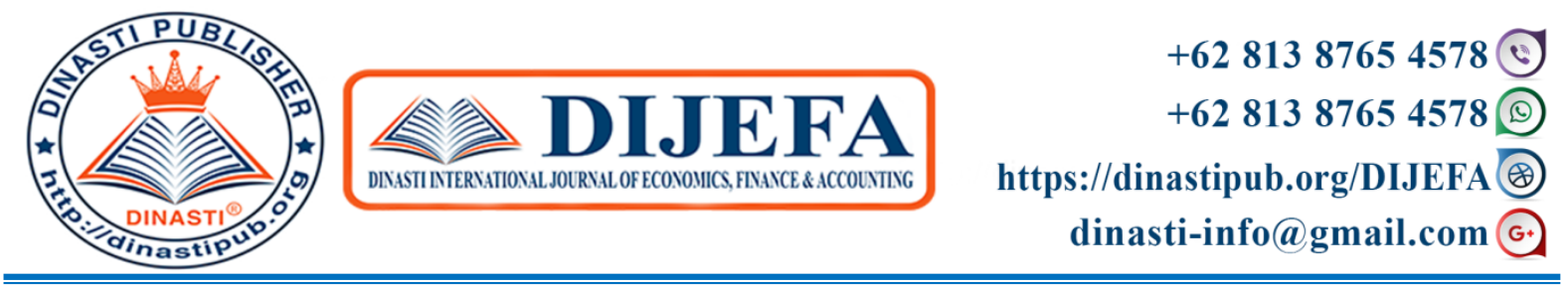

\title{
DETERMINATION ANALYSIS OF REGIONAL INCOME TOWARDS DOMESTIC REGIONAL PRODUCT WITH REGIONAL INVESTMENT AS A MODERATOR
}

\author{
Khalid Aziz ${ }^{1}$, Soeratno ${ }^{2}$, Sri Ambarwati ${ }^{3}$ \\ ${ }^{123}$ Fakultas Ekonomi Dan Bisnis, Universitas Pancasila, Jakarta, Indonesia
}

\begin{tabular}{|c|c|}
\hline $\begin{array}{l}\text { ARTICLE INFORMATION } \\
\text { Received: } 17^{\text {th }} \text { April } 2020 \\
\text { Revised: } 20^{\text {th }} \text { April } 2020 \\
\text { Issued: } 26^{\text {th }} \text { April } 2020 \\
\text { Corresponding author: } \\
\text { Sri Ambarwati } \\
\text { E-mail: } \\
\text { Sriambarwati@ univpancasila.ac.id } \\
\end{array}$ & $\begin{array}{l}\text { Abstract: Regional income is a source of income for } \\
\text { local governments that hold every activity that has an } \\
\text { allocation of funds for people. The purpose of this } \\
\text { study is to study and analyze the structure of regional } \\
\text { income with regional investment as a moderator. This } \\
\text { research was conducted at the Regency / City } \\
\text { government in West Java Province, this study uses } \\
\text { secondary data released from the APBD and PDRB } \\
\text { realization report in the period } 2014 \text { to } 2017 \text {. The } \\
\text { sample research method used was purposive sampling } \\
\text { technique. The analytical method used is the } \\
\text { Moderated Regression Analysis using Eviews } 9 . \\
\text { Based on the results of the analysis obtained from } \\
\text { regional original income, regional investment, } \\
\text { balanced funds that are moderated by regional } \\
\text { investment. Regional original income is moderated by } \\
\text { significant regional investment on gross regional } \\
\text { domestic product. The results of the study are used to } \\
\text { include local governments in managing regional } \\
\text { revenue sources and taking an assessment to make } \\
\text { regional investments. This journal is the result of his } \\
\text { own work and all sources, both quoted and referenced, } \\
\text { have been properly approved. } \\
\text { Keywords: Gross Regional Domestic Product, } \\
\text { Regional Original Revenue, Balance Funds, Other } \\
\text { Legitimate Regional Revenues, Regional Investment. }\end{array}$ \\
\hline
\end{tabular}

\section{INTRODUCTION}

Autonomy or autonomy comes from the Greek, autos which means itself and nomous nomous which means law or regulation. Based on Law No. 32/2004, it has given the regional government the freedom to regulate and manage their own regions with the aim of providing freedom and independence for the region. Regional autonomy provides space for local governments to make policies that can overcome the problems that become the needs of local communities through freedom of action, because basically this policy is expected to provide 
welfare for the community and reduce local government dependence on the central government (Azmi, 2015) . The delegation of authority from the central government to regional governments that is regulated in the legislation causes the revenue assignment and expenditure assignments to local governments (Rizal, 2007).

The authority that has been delegated to the local government consists of funds and the funds have been designed in the regional budget and expenditure which is a plan of activities in the form of numbers to improve the welfare of the community (Halim, 2012). Regional Revenue and Expenditures Budget Provided to Local Governments for Related Regional DPRDs to be Legalized and Implemented according to Planning. One indicator of the success of the implementation of regional autonomy can be seen in regional domestic products, which is seen the long-term per capita output (Nuraeni and Suratno, 2015). The performance of regional governments can be seen from several aspects, one of which is an increase in regional domestic products which indicates an increase in the welfare of the local community (Kariena, 2016).

The authority has been delegated to the regional government in the form of funding. The authority that has been delegated to the local government in the form of funding. Useage of funds has been designed in the regional income and expenditure budget which is a planned activity in the form of numbers to improve the welfare of the community (Halim, 2012). Regional budget revenues and expenditures submitted by the regional government to the relevant regional DPRD which approved and implemented according to plan. One indicator of the successful implementation of regional autonomy can be seen in the gross regional domestic product, which is seen increasing long-term output per capita (Nuraeni and Suratno, 2015). The performance of regional governments can be seen from several aspects, one of which is the increase in gross regional domestic product which indicates an increase in the welfare of the people of the area (Kariena, 2016).

West Java Province is one of the most populous provinces in Indonesia. According to BPS data in 2018 there are $18.28 \%$ of Indonesian people in West Java, it shows there is a difference of $3.34 \%$ with the total number of Indonesians on the island of Sumatra, amounting to $21.62 \%$. The population density in West Java is emphasized by the expansion of the Pangandaran regency policy based on Law No. 21 of 2012. Population growth should go hand in hand with economic growth in West Java, because basically every human always undertakes economic activities to support his living needs. The following is a table of nominal and regency / city gross regional domestic product growth in West Java Province in the period 2014 to 2017.

\section{Tabel 1}

Gross Regional Domestic Product At Constant Prices

Regencies / Cities in West Java Province 2014-2017

\begin{tabular}{|c|c|c|}
\hline Year & $\begin{array}{c}\text { GRDP } \\
\text { (in Billion Rupiah) }\end{array}$ & $\begin{array}{c}\text { GRDP } \\
\text { (in Billion Rupiah) }\end{array}$ \\
\hline 2014 & $42.436,24$ & 5.55 \\
\hline 2015 & $44.699,68$ & 5.05 \\
\hline 2016 & $47.313,99$ & 5.66 \\
\hline 2017 & $50.030,60$ & 5.29 \\
\hline
\end{tabular}


In table 1, nominal regional gross domestic product always experiences an increase, but the rate of growth of gross regional domestic domestic product has fluctuated. The fluctuation is a problem because in essence a condition is said to be good when experiencing an increase in either the nominal or delta changes. This state of fluctuation is a challenge for regional governments as the frontline in regional economic growth which is an integral part of national economic growth based on the principle of regional autonomy.

The structure of regional income is generally divided into regional own-source revenue, balancing funds, and other valid regional income (Government Regulation Number 58 of 2005). Basically, the regional income and expenditure budget is the basis for the regional government to carry out activities in one period, where the input (local own-source revenue, balance funds, etc.) is then processed through investment policies or work programs carried out by the executive (government regions) and in its implementation is overseen by the legislature (DPRD) to achieve the welfare output of the people of each region drawn through gross regional domestic product. If regional income increases, the source of regional income increases, which means that the regional government is able to process investment policies or work programs to improve the welfare of the people reflected through gross regional domestic product. The following table shows the rate of growth of regional income and district / city investment in West Java Province in the period 2014 to 2017

Tabel 2

Regional Revenue and Regional Investment Regency / City in West Java Province 2014-2017 (in Percentage)

\begin{tabular}{|c|c|c|c|c|}
\hline Tahun & $\begin{array}{c}\text { Rate } \\
\text { Regional Original } \\
\text { Revenue Growth }\end{array}$ & $\begin{array}{c}\text { Growth Rate of } \\
\text { Balancing Funds }\end{array}$ & $\begin{array}{c}\text { Other Growth Rates } \\
\text { Legitimate Local } \\
\text { Revenues }\end{array}$ & $\begin{array}{c}\text { Regional } \\
\text { Investment } \\
\text { Growth Rate }\end{array}$ \\
\hline 2014 & 38.00 & 8.00 & 25.00 & 21.30 \\
\hline 2015 & 14.80 & 3.30 & 24.00 & 32.70 \\
\hline 2016 & 90.30 & 22.60 & -27.00 & 91.20 \\
\hline 2017 & 30.10 & 6.00 & 15.40 & -60.00 \\
\hline
\end{tabular}

Regional original income is the accumulation of regional income that comes from the original economic resources of the region. Regional own-source revenue is revenue derived from regional tax revenue, regional user fees, regional corporate profits, and other legitimate regional own-source revenues (Nurcholis, 2007). Regional original income indirectly encourages regional economic growth, this can be seen in table 2 where there is a fluctuation in the growth rate of regional original income that can be indicated to cause a fluctuating gross regional domestic product growth rate.

Balancing funds are funds sourced from the central government or other regions to reduce disparities in funding sources between the center and the regions (vertical imbalance), and between regions (horizontal imbalance), and reduce disparities in public services between regions in the context of the implementation of decentralization (Law Number 33 of 2004). Balancing funds indirectly encourage regional economic growth. This can be seen in table 2 where there is a fluctuation in the growth rate of the balance fund which can be indicated to cause a fluctuating gross regional domestic product growth rate.

Other legitimate regional income is income received by the regional government outside the original regional income and the balance fund in accordance with applicable laws 
and regulations, such as grants, emergency funds, tax revenue sharing funds, adjustment funds, and special autonomy funds, as well as assistance finance from the province or from other local governments. Other legal regional income indirectly encourages regional economic growth. This can be seen in table 2 where there is a fluctuation in the other legitimate regional income rates that can be indicated to cause a fluctuating gross regional domestic product growth rate.

Regional investment can be done by local governments to manage finances in order to improve the welfare of regional or private companies with the approval of the legislative body (DPRD) (Law Number 1 of 2004). Regional investment can indirectly trigger regional economic growth, this can be seen in table 2 where there is a fluctuation in the regional investment rate that can be indicated to cause a fluctuating gross regional domestic product growth rate.

Research conducted by Laeni Najiah (2013) on the City of Depok suggests that regional own-source revenues, balancing funds affect gross regional domestic product. In other variables, legitimate regional income has no effect on gross regional domestic product based on the research of Karina Riyadi (2019) in East Java Province. Other research conducted by Jolianis (2012) on the Province of West Sumatra suggests that regional investment influences gross regional domestic product.

\section{LITERATURE REVIEW}

A budget is a tool for planning and controlling profit operations in a profit organization where the level of formality of a budget depends on the size of the organization. Glenn A. Welch in Adhim (2008) said that the budget is a form of report of plans and management policies that are used in a certain period as a guide in that period. Understanding public sector budgeting is financial planning about estimates of expenditures and revenues expected to occur in the future by looking at data obtained from the past as a reference for budgeting

Based on Law Number 32 of 2004, regional finance is all regional rights and obligations in the context of administering local governments that can be valued in money, including all forms of wealth related to the rights and obligations of the region. In the Minister of Domestic Affairs Regulation No. 13 of 2006, the guidelines for regional financial management are explained, which must be guided by general principles such as obeying the legislation, effective, efficient, economical, transparent, responsible, fairness, propriety, and benefits for the community. The ability of regional governments to manage regional finances contained in regional revenue and expenditure budgets reflects the ability of regional governments to finance government tasks, development, and social services to achieve the welfare of their people. In the Minister of Domestic Affairs Regulation Number 64 of 2013 states, "the regional income and expenditure budget is the annual financial plan of the regional government which is discussed and agreed upon by the regional government with the related DPRD and determined to be a regional regulation". If the discussion of the draft regional revenue and expenditure budget has not been agreed upon between the central government and the relevant DPRD, then to finance the needs every month the regional 
government can carry out the maximum expenditure as much as the realization of the regional budget of the previous year's revenue and expenditure (Law Number 17 Year 2003 ).

\section{Locally-generated revenue}

Regional Original Income (PAD) is all regional revenue originating from the region's original economic resources, collected according to local regulations and applicable laws and regulations (Halim, 2008). According to Law No. 33/2004 the original regional income comes from:
a. Local tax;
b. Regional levies;
c. Results of the management of separated regional assets; and
d. Other legitimate local revenue.

\section{Balance Funds}

According to Law Number 33 of 2004, balancing funds are funds originating from APBN revenues that are allocated to regions to fund regional needs in the context of implementing decentralization. The main purpose of this relationship is to achieve a balance so that the potential and resources in each region can be divided accordingly, in addition to that the equalization fund is also intended to assist the region in funding its authority which aims to reduce the imbalance of funding sources between the central government and regional governments and to reducing government funding gaps between regions. According to the Minister of Home Affairs Regulation No. 13/2006, the balance fund component is divided into: a. Profit sharing funds; b. General allocation fund; and c. Special allocation fund.

\section{Other Legal Local Revenue}

Other valid regional income is income received by the regional government outside the original regional revenue component and the balancing fund component as long as it does not conflict with applicable laws and regulations. According to Law Number 32 of 2004, other legal components of regional income are divided according to type of income which includes:

a. Grants come from the government, other regional governments, domestic private institutions / institutions / organizations, community groups / individuals, and non-binding foreign institutions;

b. Emergency funds from the government in the context of overcoming victims / damage due to natural disasters;

c. Tax revenue sharing from the province to regencies / cities;

d. Adjustment funds and special autonomy funds determined by the government; and

e. Financial assistance from the province or from other local governments. 


\section{Regional Investment}

The government can make long-term investments to obtain economic, social, and / or other benefits in the form of investments referred to in the form of shares, debt securities, and direct investments governed by central / regional government regulations (Law Number 1 of 2004). Every investment in local government must go through approval from the DPRD either to regional, state, or private companies.

\section{Gross Regional Domestic Product}

Gross Regional Domestic Product is the gross value added of all goods and services that are created or produced in the domestic territory, arising from various economic activities in a given period, regardless of whether the production factor is owned by residents or non-residents (Statistics Indonesia, 2018) . The preparation of gross regional domestic product can be done through three approaches, namely:
a. According to the Production Approach.
b. According to the Revenue Approach.
c. According to the Expenditure Approach.

The basis for calculating gross regional domestic product is divided into two, namely GRDP at current prices and at constant prices. Gross regional domestic product based on current prices are prepared based on prices prevailing in the calculation period, and aims to look at the structure of the economy. Gross regional domestic product at constant prices is based on prices in the base year with the aim of measuring economic growth. One important indicator to know the condition of the economy in a region / region within a certain period can be illustrated from the gross regional domestic product data (Badan Pusat Statistik, 2017).

\section{Framework for Thinking and Hypothesis}

Based on research background, literature review, and previous research. So the systematic framework of thinking in this study can be seen in Figure 1.

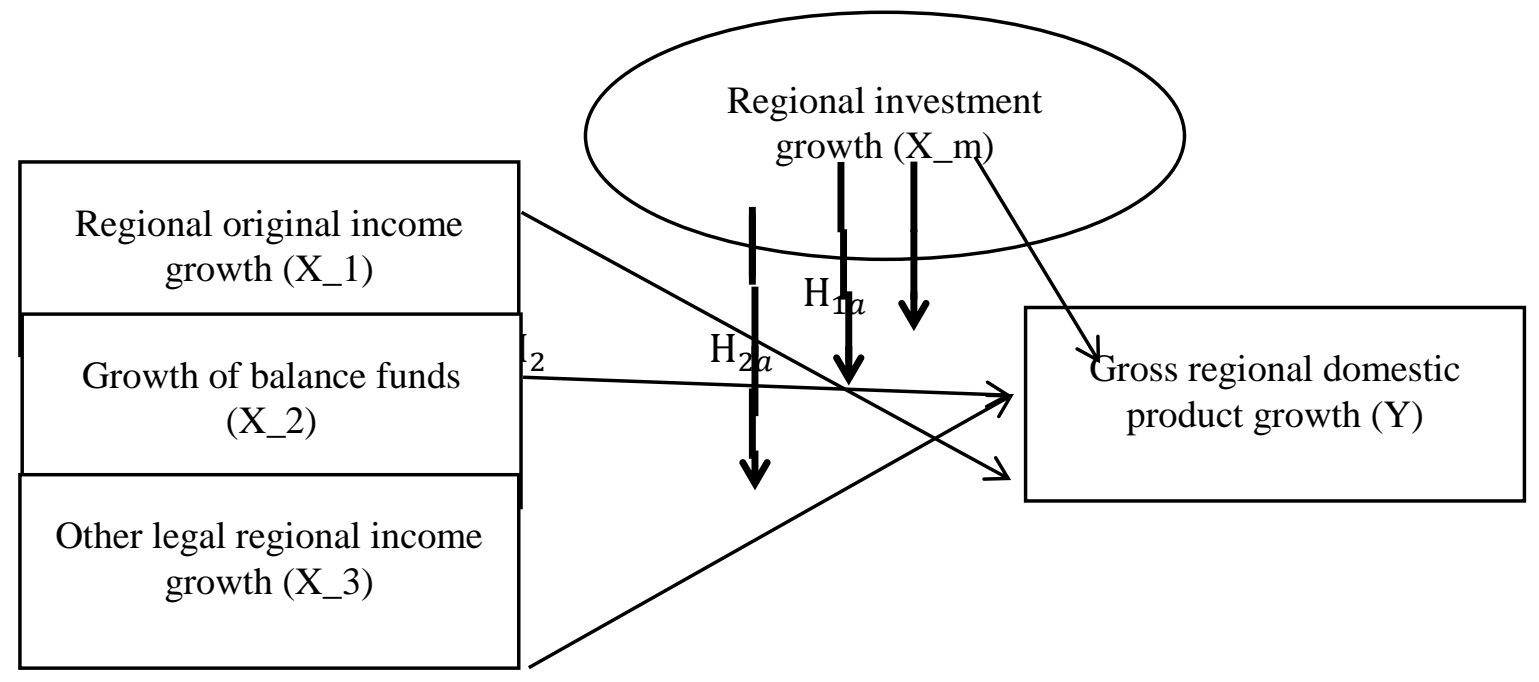

Figure 1: A theoretical framework 
Based on the above framework of thought and theoretical support, the writer makes a hypothesis. The hypothesis is interpreted as a presumption or assumption that must be tested through data and facts obtained by research (Dantes, 2012). The following hypotheses are developed:

$\mathrm{H}_{1}$ : Regional original income growth has a significant effect on the growth of gross regional domestic product.

$\mathrm{H}_{2}$ : The growth of balance funds has a significant effect on the growth of gross regional domestic product.

$\mathrm{H}_{3}$ : Other legal regional income growths have a significant effect on the growth of gross regional domestic product.

$\mathrm{H}_{4}$ : Regional investment growth has a significant effect on the growth of gross regional domestic product.

$\mathrm{H}_{1 a}$ : Regional original income growth moderated by regional investment growth has a significant effect on the growth of gross regional domestic product.

$\mathrm{H}_{2 a}$ : Pthe growth of balanced funds which is moderated by regional investment growth significantly influences the growth of gross regional domestic product.

$\mathrm{H}_{3 a}$ : Other legal regional income growth which is moderated by regional investment growth has a significant effect on the growth of gross regional domestic product.

Based on the above framework of thought and theoretical support, the writer makes a hypothesis. The hypothesis is interpreted as a presumption or assumption that must be tested through data and facts obtained by research (Dantes, 2012). The following hypotheses are developed:

H1: The growth of regional original income has a significant effect on the growth of gross regional domestic product.

$\mathrm{H} 2$ : The growth of balance funds has a significant effect on the growth of gross regional domestic product.

H3: Other legal regional income growth has a significant effect on the growth of gross regional domestic product.

H4: Regional investment growth has a significant effect on the growth of gross regional domestic product.

H1a: Regional original income growth moderated by regional investment growth has a significant effect on the growth of gross regional domestic product.

$\mathrm{H} 2 \mathrm{a}$ : The growth of balanced funds which is moderated by regional investment growth has a significant effect on the growth of gross regional domestic product.

H3a: Other legitimate regional income growth which is moderated by regional investment growth has a significant effect on the growth of gross regional domestic product.

\section{RESEARCH METHODS}

This research was conducted using quantitative and descriptive approaches. Quantitative research is research that uses many numbers such as data collection, interpretation of the data and the appearance of the results (Arikunto, 2016). Descriptive 
research is research conducted by collecting and analyzing and presenting data in connection with the problem under study so as to give a clear picture of the object of research and in making decisions (Sanusi, 2014). This research is also correlational in nature which aims to find out the relationship between two or more variables, in this study there are three variables in this study. The independent variable or the independent variable (X), among others, is the growth of regional original income growth, the growth of balancing funds, and other legal regional income growths. The second variable is the dependent variable or the dependent variable (Y), including the growth rate of gross regional domestic product. In this study there is a moderating variable that is the growth rate of regional investment. The data obtained will then be processed using e-views 9.0 to find out how the relationship and influence between the independent variables on the dependent variable is moderated by the moderating variable.

The type of data used is secondary data, secondary data is data obtained through other parties (Sugiyono, 2014). The data used in this study came from the APBD realization report and the regional gross domestic product report with the price method for Regencies and Cities in West Java Province. The sample is part of the number of characteristics possessed by the population due to certain limitations (Setiawan, 2014). For the sampling technique used in this study is a purposive sampling technique which is a sampling method that is in accordance with certain considerations.

\section{Operationalization of Variables}

The operational definitions of variables and their measurements are as follows

1. Growth of regional own-source revenue is the result of the calculation of total regional own-income this year reduced by total regional own-source revenue last year, then divided by total regional own-source revenue last year, and multiplied by one hundred percent so that the results reach percent.

$$
\triangle P A D=\frac{\left(P A D_{t}-P A D_{t-1}\right)}{P A D_{t-1}} \times 100 \%
$$

2. The growth of the balance fund $\left(X_{2}\right)$

The growth of the balance fund is the result of the calculation of the total balance funds now reduced by the total balance funds last year, then divided by the total balance funds last year, and multiplied by one hundred percent so that the results reach percent.

$$
\triangle D P=\frac{\left(D P_{t}-D P_{t-1}\right)}{D P_{t-1}} \times 100 \%
$$

3. Other growth of legal regional income $\left(\mathrm{X}_{3}\right)$

Other growth of legal regional income is a result of the calculation of total other regional revenue that is valid this year reduced by the total other regional income that is valid in the previous year, then divided by total other regional income that is valid in the previous year, and multiplied by one hundred percent so the results reach percent.

$$
\triangle L P D=\frac{\left(L P D_{t}-L P D_{t-1}\right)}{L P D_{t-1}} X 100 \%
$$


4. Regional investment growth $\left(\mathrm{X}_{m}\right)$

Regional investment growth is the result of the calculation of total regional investment this year reduced by total regional investment last year, then divided by regional investment last year, multiplied by one hundred percent so that the results reach percent.

$$
\Delta I n v=\frac{\left(\operatorname{In} v_{t}-\operatorname{In} v_{t-1}\right)}{\operatorname{In} v_{t-1}} \times 100 \%
$$

5. Gross regional domestic product growth ( $\mathrm{Y}$ )

Gross regional domestic product growth is the result of the calculation of the total gross regional domestic product this year reduced by the total regional gross domestic product last year, then divided by the regional gross domestic product last year, multiplied by one hundred percent so that the results reach percent.

$$
\triangle P D R B=\frac{\left(P D R B_{t}-P D R B_{t-1}\right)}{P D R B_{t-1}} \times 100 \%
$$

6. Gross Regional Domestic Product Growth ( 『Y】_)

Gross regional domestic product growth is the result of the calculation of the total gross regional domestic product this year reduced by the total regional gross domestic product last year, then divided by the regional gross domestic product last year, multiplied by one hundred percent so that the results reach percent.

The regression technique chosen in this study is panel data, which is a combination of types of data that is cross-section data and time series. This study uses several analytical methods in answering the objectives to be achieved. The analysis tool includes:

1. Panel data estimation, panel data combined between time series data and cross section data. Data is taken every day. Model testing can simplify research and focus more on accepted models, test models include:

a. Chow test is a test to determine the fixed effect model or random effect that is most appropriate to be used in estimating panel data.

b. Hausman test is a statistical test to determine whether the fixed effect model or the random effect is most appropriate to be used in estimating panel data.

c. The legrange multiplier test is a statistical test to determine whether random effects models or general effects are most appropriate to be used in estimating panel data.

2. The classic assumption test is one of the prerequisite tests for multiple regression. The classic assumption test is only enough to test the model accepted in the test model to be used in estimating panel data. Test classic assumptions, including:

a. The normality test aims to test whether in the regression model the data interrupt or residual data has a normal distribution or not. The data used must be normally distributed (Ghozali, 2016). Variations in data are normally distributed if greater than $5 \%$ significance. 
b. Multicollinearity test aims to test whether the regression model found a correlation between independent variables (Ghozali, 2016). Variation of data is said to be free of multicollinearity symptoms if the coefficient value is below 0.8 .

c. The heteroscedasticity test aims to test whether there are similarities in the variance of the residuals for all observations in the linear regression model. If each independent variable does not significantly influence the absolute residual (significance of 5\%), then the regression model does not occur heteroscedasticity (Sanusi, 2014).

d. The autocorrelation test aims to test whether in a linear regression model there is a correlation between the error of the interrupt in the current period and the error of the previous period. The autocorrelation test was not used in this study, because this test uses panel data and there is no feature of this test in e-views 9.0.

3. Regression moderation analysis, conducted to predict the strength of the influence of the independent variable on the dependent variable by being moderated by the moderating variable. So the models that can be formed are:

$\mathbf{Y}=\mathbf{a}+\boldsymbol{\beta}_{1} \cdot \mathbf{X}_{1}+\boldsymbol{\beta}_{2} \cdot \mathbf{X}_{2}+\beta_{3} \cdot \mathbf{X}_{3}+\beta_{4} \cdot \mathbf{X}_{m}+\beta_{5} \cdot X_{1} \cdot X_{m}+\beta_{6} \cdot X_{2} \cdot X_{m}+\beta_{7} \cdot X_{3} \cdot X_{m}+e$

Keterangan :

$\mathrm{Y}=$ Gross regional domestic product growth rate

$\alpha \quad=$ Constant

$\beta \quad=$ Slope or regression coefficient

$\mathrm{X}_{1} \quad=$ Growth of locally-generated revenue

$\mathrm{X}_{2} \quad=$ Growth of balance funds

$\mathrm{X}_{3} \quad=$ Other regional income growths

$\mathrm{X}_{m}=$ Growth in regional investment (capital) investment

$\mathrm{e}=$ Standard error or confounding variable

4. Hypothesis testing

Test the coefficient of determination $\left(\mathrm{R}^{2}\right)$ to measure how much the independent variable can explain the dependent variable. The value used is the adjusted value $R^{2}$.

Statistical test $\mathrm{t}$ ( $\mathrm{t}$-test) to determine the magnitude of the influence of individual independent variables in explaining the dependent variable significantly. Social research is permitted to use interval levels of $1 \%, 5 \%$, or $10 \%$ and according to Hair et al in Galuh (2019) states a significance level of $10 \%$ is suitable for studies with limited sample sizes.

\section{FINDINGS AND DISCUSSION}

Hasil Uji Statistik Deskriptif

Tabel 3

Hasil Statistik Deskriptif (dalam Persentase)

\begin{tabular}{|l|c|c|c|c|c|}
\hline \multicolumn{1}{|c|}{ Variable } & N & $\begin{array}{c}\text { Minimu } \\
\text { m }\end{array}$ & Maxsimum & Mean & $\begin{array}{c}\text { Std. } \\
\text { Deviation }\end{array}$ \\
\hline $\begin{array}{l}\text { Gross Regional Domestic Product } \\
\text { Growth }\end{array}$ & 40 & 4.31 & 6.43 & 5.55 & 0.57 \\
\hline Regional Original Revenue Growth & 40 & -8.08 & 118.88 & 31.85 & 29.19 \\
\hline Growth of Balancing Funds & 40 & -14.97 & 27.27 & 8.05 & 9.93 \\
\hline Miscellaneous Growth of Legal & 40 & -82.61 & 393.80 & 21.56 & 68.45 \\
\hline
\end{tabular}




\begin{tabular}{|l|c|c|c|c|c|}
\hline Local Revenue & & & & & \\
\hline Regional Investment Growth & 40 & -90.00 & 733.33 & 39.91 & 132.50 \\
\hline
\end{tabular}

Descriptive statistics can be presented as follows:

1. Gross Regional Domestic Product Growth

From 40 sample data, the highest gross regional domestic product growth is $6.43 \%$ and the lowest is $4.31 \%$. The average value of $5.55 \%$ is greater than the standard deviation of $0.57 \%$, meaning that the data studied is quite good because its spread is normal and does not cause bias.

2. Regional Original Revenue Growth

From 40 data samples, the highest growth of regional original income is $118.88 \%$ and the lowest is $-8.08 \%$. The average value of $31.85 \%$ is greater than the standard deviation of $29.19 \%$, meaning that the data studied is quite good because the spread is normal and does not cause bias

3. Growth of Balancing Funds

From 40 data samples, the highest balance fund growth was $27.27 \%$ and the lowest was $-14.97 \%$. The average value of $8.05 \%$ is smaller than the standard deviation of $9.93 \%$, meaning that the data studied is not good because of high deviations and can cause bias in the spread of data.

4. Miscellaneous Growth of Legal Local Revenue

From 40 data samples, the highest growth of other regional income was $393.80 \%$ and the lowest was $-82.61 \%$. The average value of $21.56 \%$ is smaller than the standard deviation of $68.45 \%$, meaning that the data studied is not good because of high deviations and can cause bias in data distribution.

5. Regional Investment Growth

From 40 data samples, the highest regional investment growth was $733.33 \%$ and the lowest was $-90.00 \%$. The average value of $39.91 \%$ is smaller than the standard deviation of $132.50 \%$, meaning that the data studied is not good because of high deviations and can cause bias in the distribution of data.

\section{Data Estimation Test Results}

\section{Tabel 4}

Hasil Uji Estimasi Data

\begin{tabular}{|l|l|l|}
\hline \multicolumn{1}{|c|}{ Uji Estimasi Data } & \multicolumn{1}{|c|}{ Hasil Uji } & \multicolumn{1}{|c|}{ Kesimpulan } \\
\hline Chow test & $\begin{array}{l}\text { cross section F Chi-square } \\
(0.0000)<0,05\end{array}$ & fixed effect model \\
\hline Hausman test & Prob. $(0.0010)<0,05$ & fixed effect model \\
\hline $\begin{array}{l}\text { Lagrange Multiplier } \\
\text { test }\end{array}$ & $\begin{array}{l}\text { Breusch-Pagan (0.0025) < } \\
0.05\end{array}$ & random effect model \\
\hline
\end{tabular}

Based on the results of the data estimation test in table 4 above, we get the random effect model selected once and the fixed effect model selected twice, so that the best model for regression in this study is the fixed effect model. 


\section{Classic Assumption Test Results}

The classic assumption test is done by selecting the fixed effect model. This study uses a classic assumption test which includes a normality test, a heteroscedasticity test, and a multicolinearity test.

\section{Tabel 5}

\section{Hasil Uji Asumsi Klasik}

\begin{tabular}{|l|l|l|}
\hline \multicolumn{1}{|c|}{ Classic assumption test } & \multicolumn{1}{|c|}{ Test Result } & \\
\hline Normalitas test & P-value $(0.796371)>0,05$ & Residual Normal \\
\hline Heteroskedastisitas test & Prob. $X_{1}(0.2599)>0.05$ & No Heteroscedasticity Occurs \\
& Prob. $X_{2}(0.8721)>0.05$ & \\
& Prob. $X_{3}(0.0618)>0.05$ & \\
& Prob. $X_{m}(0.8167)>0.05$ & \\
& Prob. $X_{1} X_{m}(0.6956)>0.05$ & \\
& Prob. $X_{2} X_{m}(0.7793)>0.05$ & \\
& Prob. $X_{3} X_{m}(0.9217)>0.05$ & \\
\hline
\end{tabular}

Based on the results of the classic assumption test in table 5, it is proven that:

1. The data have normal residuals, this is in accordance with the results of the normality test above, can be seen with the Jarque-Bera value and concluded that the probability value (P-value) is 0.796371 which means the value of $\mathrm{P}$-value> $0.05(0.796371>0.05)$. In conclusion $\mathrm{H} 0$ is accepted and $\mathrm{H} 1$ is rejected, meaning that the residual data is normally distributed.

2. The data is free from heteroscedasticity, this is in accordance with the results of the heteroscedasticity test above, it can be seen that the probability value ( $\mathrm{P}$-value) of $\mathrm{X} 1$ growth of regional original income), X2 (growth of funds balance), X3 (other legal regional income growth), and X4 (regional investment growth) have probability values above 0.05 . The results of this test indicate that there is no heteroscedasticity among the independent variables of the study.

\section{Tabel 6}

\section{Hasil Uji Multikolinearitas}

$\begin{array}{lllllll}X_{1} & X_{2} & X_{3} & X_{m} & X_{1} X_{m} & X_{2} X_{m} & X_{3} X_{m}\end{array}$

\begin{tabular}{|c|c|c|c|c|c|}
\hline$X_{1}$ & $1.000000-0.363121$ & -0.068816 & 0.231984 & 0.280084 & 0.0704370 .030691 \\
\hline \multirow[b]{2}{*}{$X_{2}$} & & & & \multicolumn{2}{|r|}{0.38583} \\
\hline & $-0.363121 \quad 1.000000$ & -0.020060 & -0.126320 & -0.146484 & $9 \quad-0.088829$ \\
\hline \multirow[t]{2}{*}{$X_{3}$} & $-0.068816-0.020060$ & 1.000000 & -0.140524 & -0.081679 & $0.130722-0.204251$ \\
\hline & & & & \multicolumn{2}{|r|}{0.31824} \\
\hline \multirow[t]{2}{*}{$X_{m}$} & $0.231984-0.126320$ & -0.140524 & 1.000000 & 0.921470 & $\begin{array}{ll}6 & -0.080989\end{array}$ \\
\hline & & & & \multicolumn{2}{|r|}{0.06889} \\
\hline $\mathrm{X}_{1} \mathrm{X}_{m}$ & $0.280084-0.146484$ & -0.081679 & 0.921470 & 1.000000 & $6 \quad-0.219223$ \\
\hline $\mathrm{X}_{2} X_{m}$ & $-0.070437 \quad 0.385839$ & -0.130722 & 0.318246 & 0.068896 & $1.00000^{0.083526}$ \\
\hline
\end{tabular}




$$
\begin{aligned}
& 0 \\
& \begin{array}{llllllll}
\mathrm{X}_{3} \mathrm{X}_{m} & 0.030691 & -0.088829 & -0.204251 & -0.080989 & -0.219223 & 6 & 1.0000000
\end{array}
\end{aligned}
$$

The coefficient number is $\mathrm{Xm}$ and $\mathrm{X} 1 \mathrm{Xm}$ are more than $0.80, \mathrm{H} 0$ is rejected and indicates that the data has multicollinearity symptoms. If there is a correlation between independent variables, one of them can be overcome by using the centering method (Ghozali, 2016). To overcome this, centering on $X 1$ is done in table 7 below.

\section{Tabel 7}

\section{Hasil Uji Multikolinearitas Centering}

\begin{tabular}{cccccccc} 
& \multicolumn{1}{c}{$\boldsymbol{C} \boldsymbol{X}_{\mathbf{1}}$} & $\boldsymbol{X}_{\mathbf{2}}$ & $\boldsymbol{X}_{\mathbf{3}}$ & $\boldsymbol{X}_{\boldsymbol{m}}$ & $\mathbf{C X}_{\mathbf{1}} \mathbf{X}_{\boldsymbol{m}}$ & $\mathbf{X}_{\mathbf{2}} \boldsymbol{X}_{\boldsymbol{m}}$ & $\mathbf{X}_{\mathbf{3}} \mathbf{X}_{\boldsymbol{m}}$ \\
\hline \hline$C X_{1}$ & 1.000000 & -0.363121 & -0.068816 & 0.231984 & 0.287975 & -0.070437 & 0.030691 \\
$X_{2}$ & -0.363121 & 1.000000 & -0.020060 & -0.126320 & -0.147360 & 0.385839 & -0.088829 \\
$X_{3}$ & -0.068816 & -0.020060 & 1.000000 & -0.140524 & -0.036519 & -0.130722 & -0.204251 \\
$X_{m}$ & 0.231984 & -0.126320 & -0.140524 & 1.000000 & 0.793219 & 0.318246 & -0.080989 \\
$\mathrm{CX}_{1} \mathrm{X}_{m}$ & 0.287975 & -0.147360 & -0.036519 & 0.793219 & 1.000000 & -0.099268 & -0.290909 \\
$\mathrm{X}_{2} X_{m}$ & -0.070437 & 0.385839 & -0.130722 & 0.318246 & -0.099268 & 1.000000 & 0.083526 \\
$\mathrm{X}_{3} \mathrm{X}_{m}$ & 0.030691 & -0.088829 & -0.204251 & -0.080989 & -0.290909 & 0.083526 & 1.000000
\end{tabular}

The results of multicollinearity test after centering in table 7 show no coefficient of more than 0.80 . Therefore the classic assumption test has passed to do the hypothesis test.

Tabel 8

Hasil Uji Hipotesis

\begin{tabular}{|l|l|l|}
\hline \multicolumn{1}{|c|}{ Variabel } & Coefficient & \multicolumn{1}{|c|}{ Prob. } \\
\hline Constant & 5.33532 & 0.0000 \\
\hline Growth of Local Own Revenue $\left(X_{1}\right)$ & -0.00061 & 0.8303 \\
\hline Growth of Balancing Funds $\left(X_{2}\right)$ & 0.02195 & 0.0184 \\
\hline Other Growth of Legitimate Regional Income $\left(X_{3}\right)$ & 0.00189 & 0.0782 \\
\hline Growth of Capital Expenditures $\left(X_{m}\right)$ & -0.00227 & 0.02749 \\
\hline $\begin{array}{l}\text { Growth of Regional Original Income in Regional } \\
\text { Investment Moderation }\left(\mathrm{X}_{1} \mathrm{X}_{m}\right)\end{array}$ & 0.00004 & 0.0666 \\
\hline $\begin{array}{l}\text { Growth of Regional Investment Moderation Investment } \\
\text { Funds }\left(\mathrm{X}_{2} \mathrm{X}_{m}\right)\end{array}$ & 0.00010 & 0.3331 \\
\hline $\begin{array}{l}\text { Miscellaneous Growth of Legitimate Regional Income } \\
\text { Regional Investment Moderation }\left(\mathrm{X}_{3} \mathrm{X}_{m}\right)\end{array}$ & 0.00002 & 0.2916 \\
\hline R-squared =0.710885 & \\
\hline Adjusted R-squared = 0.509761 & \\
\hline
\end{tabular}

Based on the outputs in table 8 above, the equation from the panel data regression results can be explained as follows:

$\mathrm{Y}=5.33532+(-0.00061)\left(\mathrm{X}_{1}\right)+0.02195\left(\mathrm{X}_{2}\right)+0.00189\left(\mathrm{X}_{3}\right)+(-0.00227)\left(\mathrm{X}_{\mathrm{m}}\right)+$ $0.00004\left(X_{1} X_{m}\right)+0.00010\left(X_{2} X_{m}\right)+0.00002\left(X_{3} X_{m}\right)$ 
The interpretations of the regression equation are:

Constant : 5.33532 this means that if the growth of regional own-source revenue, the growth of equilibrium funds, other legitimate growth of regional income, and capital expenditure growth is constant or equal to zero, then the growth value of the gross regional domestic product is positive at 5.33532 units.

$\mathrm{X}_{1}$ : 0.00061 it means that every 1 percent increase in local revenue growth, the gross regional domestic product growth will decrease by 0.00061 units, assuming the other variables are fixed.

$X_{2}: 0,02195$ it means that for each increase in growth of the balance fund by 1 unit, the growth of gross regional domestic product will increase by 0.02195 units, assuming the other variables remain.

$\mathrm{X}_{3}: 0.00189$ means that for each increase in other legal regional income growth of 1 unit, the growth of gross regional domestic product will increase by 0.00189 units, assuming the other variables remain.

$X_{m}: 0.00227$ it means that each increase in regional investment growth is 1 unit, then the growth of gross regional domestic product will decrease by 0.00227 units, assuming the other variables remain.

$\mathrm{X}_{1} \mathrm{X}_{\mathrm{m}}$ : 0,00004 This means that each increase in regional revenue growth is moderated by 1 unit of regional investment growth, then the growth of gross regional domestic product will increase by 0.00004 units, assuming the other variables are fixed.

$\mathrm{X}_{2} \mathrm{X}_{\mathrm{m}}$ : 0,00010 This means that each increase in the growth of the balance fund is moderated by the growth of regional investment by 1 unit, then the growth of gross regional domestic product will increase by 0.00010 units, assuming the other variables are fixed.

$\mathrm{X}_{3} \mathrm{X}_{\mathrm{m}}: 0,00002$ This means that for any increase in other legal regional income growth that is moderated by 1 unit regional investment growth, the growth of gross regional domestic product will increase by 0.00002 units, assuming the other variables are fixed.

\section{T Test Results}

Based on the outputs in table 8 above, the results of the statistical t test that serves to determine the effect of the dependent variable partially on the independent variable assuming other variables are constant, can be explained as follows:

1. The first alternative hypothesis $\mathrm{H} 2$ states that the growth of regional original income has a significant effect on the growth of gross regional domestic product. Based on statistical parameters, it shows that the probability value of $0.8033>0.1$ means that the growth of regional original income has no significant effect on the growth of gross regional domestic product. Then the conclusion rejects $\mathrm{H} 1$ and accepts $\mathrm{H} 0$.

2. The second alternative hypothesis $\mathrm{H} 2$ states that the growth of the balance fund has a significant effect on the growth of the gross regional domestic product. Based on statistical parameters, it shows that the probability value of $0.0184<0.1$ means that the growth of the balance fund has a significant effect on the growth of gross regional domestic product. Then the conclusion is to accept $\mathrm{H} 2$ and reject 
3. The third alternative hypothesis H3 states that other legal regional income growth has a significant effect on the growth of gross regional domestic product. Based on statistical parameters, it shows that the probability value of $0.0782<0.1$ means that other growth of legitimate regional income has no significant effect on the growth of gross regional domestic product. Conclusion accept $\mathrm{H} 3$ and reject $\mathrm{H} 0$.

4. The fourth alternative hypothesis $\mathrm{H} 3$ states that the growth of regional investment has a significant effect on the growth of gross regional domestic product. Based on statistical parameters, it shows that $\mathrm{t}$ arithmetic of $0.2749>0.1$ means that regional investment growth has no significant effect on the growth of gross regional domestic product. Conclusion reject $\mathrm{H} 4$ and accept $\mathrm{H} 0$.

5. The fifth alternative hypothesis H1a states that the growth of regional original income which is moderated by regional investment growth has a significant effect on the growth of gross regional domestic product. Based on statistical parameters, it shows that the probability value of $0.0666<0.1$ means that the growth of regional original income moderated by regional investment growth has a significant effect on the growth of gross regional domestic product. Then the conclusion is to accept $\mathrm{H} 1 \mathrm{a}$ and reject $\mathrm{H} 0$.

6. The sixth alternative hypothesis $\mathrm{H} 2 \mathrm{a}$ states that the growth of equilibrium funds which is moderated by regional investment growth has a significant effect on the growth of gross regional domestic product. Based on statistical parameters, it shows that the probability value of $0.3331>0.1$ means that the growth of equilibrium funds which is moderated by regional investment growth has no significant effect on the growth of gross regional domestic product. Then the conclusion rejects $\mathrm{H} 2$ and accepts $\mathrm{H} 0$

\section{Coefficient of Determination}

From the outputs in table 8 , the adjusted R-Square value $=0.509761$ shows that the influence given by the three independent variables, moderating variables, and moderated independent variables affects $50.97 \%$ of the dependent variable and the remaining $49.03 \%$ is influenced by other variables outside the studied variables in this research.

\section{CONCLUSION}

This study aims to determine the effect of regional revenue growth, balance fund growth, other legal regional income growth, regional investment growth, regional original income growth moderated by regional investment growth, balanced fund growth growth moderated by regional investment growth, and other growth other legitimate regional income which is moderated by regional investment growth to the growth of gross regional domestic product with an empirical study of regencies and cities in West Java province during the 2014-2017 period. Based on the results of the study, the conclusions of this study can be described as follows:

1. The growth of regional original income does not have a significant effect on the growth of gross regional domestic product. This is because the growth of local revenue in several districts and cities in West Java Province is still fluctuating every year, which shows that the revenue sector has not been running optimally. Local revenue is deemed to have a 
smaller influence ratio compared to other regional revenue structures, this could be due to governance that is not carried out effectively and efficiently.

2. The growth of balance funds has a significant effect on the growth of gross regional domestic product. This is because the allocation of balancing funds is more flexible originating from the transfer funds of the central government or other local governments, which can be used for the construction of public facilities and infrastructure, increasing gross regional domestic product, and economic growth. The existence of a close influence has an adverse effect on research this time, indirectly the purpose of regional autonomy was not well implemented as indicated by the dependence of gross regional domestic product on regional income on the balance fund post

3. Other legal regional income growths have a significant effect on the growth of gross regional domestic product. This is because the allocation of these structures comes from grants or grants which incidentally do not originate from the area's activities. The close influence has a bad effect on this study, this is because the structure of the other legitimate regional income is dominantly derived from aid or grants.

4. The growth of regional investment does not have a significant influence on the growth of gross regional domestic product. This indicates that the growth of regional investment is not effective in helping to increase gross regional domestic product.

5. The growth of regional original income which is moderated by regional investment growth has a significant influence on the growth of gross regional domestic product. This is due to the close relationship between the structure of regional original income, regional investment, and gross regional domestic product. Regional investment can strengthen the relationship between regional original income and gross regional domestic product, after in conclusion one does not have a significant effect.

6. The growth of balanced funds which is moderated by regional investment growth does not have a significant effect on the growth of gross regional domestic product. This is because there is no relationship between the balancing fund variables with regional investment. Regional investment can weaken the relationship between balance funds and gross regional domestic product, after the conclusion of the two having a significant effect.

7. Other legal regional income growth which is moderated by regional investment growth does not have a significant influence on the growth of gross regional domestic product. This is because there is no relationship between other variables of legitimate regional income with regional investment. Regional investment can weaken the relationship between legal regional income and gross regional domestic product, after the conclusion three have a significant effect.

8. The growth of balanced funds which is moderated by regional investment growth does not have a significant effect on the growth of gross regional domestic product. This is because there is no relationship between the balancing fund variables with regional investment. Regional investment can weaken the relationship between balance funds and gross regional domestic product, after the conclusion of the two having a significant effect. 
9. Other legal regional income growth which is moderated by regional investment growth has no significant effect on the growth of gross regional domestic product. This is because there is no relationship between other variables of legitimate regional income with regional investment. Regional investment can weaken the relationship between legal regional income and gross regional domestic product, after in conclusion three have a significant effect

\section{Implication}

Based on the results of the discussion and conclusions obtained, it can be analyzed the theoretical and managerial implications for the District / City Government in West Java Province, including:

1. The theoretical implications of the variables tested starting from the original regional income is income derived from the regional economic activities which should have a correlation with gross regional domestic product. The second variable is the Balancing fund is income derived from transfer funds for the balance of the central government or other local governments, if too dependent indicates one bad thing. For this third variable, the impact is not far from the balancing fund, other legitimate regional income derived from aid, grant funds, or other structures are not original regional income and the balance fund is not contrary to the law. Finally the moderating variable is regional investment which should have an influence on gross regional domestic product, because basically the structure of gross regional domestic product can come from investment

2. The managerial implication for the local government is to improve the governance of the regional revenue agency so that the road is more effective and efficient, this can encourage the influence of local revenue on gross regional domestic product. Regional governments must reduce dependency through balancing funds or other legitimate regional income to achieve the goal of regional autonomy. Local governments must also be accustomed to investing for the wealth of their regions, this is one way to improve the welfare of their local communities

\section{Limitations and Next Agenda}

This research has been carried out in accordance with scientific procedures, it's just that there are still shortcomings in this study such as the limited number of samples and the significance value used is $10 \%$. The next research agenda has a focal point on regional spending either as an independent variable or moderation, the research agenda here is to advance the regional economy and help the central government implement regional autonomy. Researchers have confidence that the regional gross domestic product of regions in Indonesia is high which is an integral part of Indonesia's gross domestic product as a whole so that it can make Indonesia a developed.

\section{REFERENCE}

Anwar, Sanusi. (2014). Metedologi Penelitian Bisnis. Jakarta: Salemba Empat 
Arikunto. (2010). Prosedur Penelitian Suatu Pendekatan Praktik. Jakarta: Rineke Cipta

Badan Pusat Statistik. (2017). Produk Domestik Regional Bruto: Provinsi Jawa Barat Menurut Pengeluaran 2013-2017. Jakarta: BPS

Badan Pusat Statistik. (2018). Produk Domestik Regional Bruto: Provinsi Jawa Barat Menurut Lapangan Usaha 2013-2017. Jakarta: BPS

Bastian, Indra S.E., Akt., M.B.A., Ph.D. (2002). Akuntansi Sektor Publik: Suatu Pengantar. Jakarta: Erlangga

Dantes, N. (2012). Metedologi Penelitian. Yogyakarta: ANDI

Febriantin, Kariena. (2016). Faktor Pemimpin dan Kepemimpinan dalam Tata Kelola Pemerintahan di Kabupaten Purwakarta Periode 2008-2015. Volume 1, hal: 43

Fendri, Azmi. (2015). Kebebasan Bertindak Pemerintah (Diskresi) Sebagai Perwujudan Nilai-Nilai Moral dan Etika. Volume 4, hal: 149

Ghozali, I. (2016). Aplikasi Analisis Multivariete dengan Program IBM SPSS 23 (Edisi 8) Cetakan VIII. Semarang: Universitas Dipenogoro

Halim, Abdul. (2008). Akuntansi Keuangan Daerah Edisi 3 Cetakan 3. Jakarta: Salemba Empat

Halim, Abdul., dan Kusufi, S. (2012). Akuntansi Sektor Publik: Teori, Konsep dan Aplikasi. Jakarta: Salemba Empat

Jolianis. (2012). Analisis Perekonomian Daerah dan Pendapatan Asli Daerah Kabupaten/Kota di Provinsi Sumatera Barat. Vol 1, hal: 62 - 63

Maranatha, Galuh. (2019). Pengaruh Ukuran Perusahaan, Profitabilitas, dan Solvabilitas terhadap Audit Delay pada Perusahaan Perbankan yang Terdaftar di Bursa Efek Indonesia pada Tahun 2016-2017. Skripsi. Program Sarjana. Jakarta: Universitas Pancasila

Mardiasmo. (2002). Akuntansi Sektor Publik.Yogyakarta: ANDI

Najiah, Laeni. (2013). Analisis Pengaruh Pendapatan Asli Daerah, Dana Perimbangan, dan Tingkat Partisipasi Angkatan Kerja Terhadap PDRB di Kota Depok Periode 20012010. Skripsi. Program Sarjana. Jakarta: UIN Syarif Hidayatullah

Nur'aeni, Yeni dan Suratno. (2015). Pengaruh PAD, DAU, DAK, dan DOK Terhadap Produk Domestik Regional Bruto. JRAP Vol. 2, hal: 32-42

Nurcholis, Hanif. (2007). Teori dan Praktik Pemerintahan dan Otonomi Daerah. Jakarta: PT. Gramedia Widiasarana Indonesia

Peraturan Menteri Dalam Negeri No. 13 Tahun 2006 tentang Pedoman Pengelolaan Keuangan

Peraturan Menteri Dalam Negeri No. 64 Tahun 2013 tentang Penerapan Standar Akuntansi Pemerintahan Berbasis Akrual Pada Pemerintah Daerah

Peraturan Pemerintah Nomor 58 Tahun 2005 tentang Pengelolaan Keuangan Daerah 
Ramadhani, Rizal. (2007). Pengaruh Otonomi Daerah Terhadap Pertumbuhan Ekonomi Wilayah Kabupaten Sukabumi. Skripsi. Program Sarjana Ilmu Ekonomi. Bogor: Institut Pertanian Bogor

Riyadi, Karina. (2019). Analisis Pertumbuhan Pendapatan Daerah dan Pertumbuhan Belanja Modal Terhadap Pertumbuhan Produk Domestik Regional Bruto Jawa Timur Periode 2012-2015. Skripsi. Program Sarjana. Jakarta: Universitas Pancasila

Sugiyono. (2014). Metode Penelitian Pendidikan Pendekatan Kuantitatif dan R\&D. Bandung: Alfabeta

Undang-Undang Nomor 17 Tahun 2003 tentang Keuangan Negara

Undang-Undang Nomor 1 Tahun 2004 tentang Perbendaharaan Negara

Undang-Undang Nomor 32 Tahun 2004 tentang Pemerintah Daerah

Undang-Undang Nomor 33 Tahun 2004 tentang Perimbangan Keuangan Antara Pemerintah Pusat dan Pemerintah Daerah 